\title{
A NOTE ON
}

\section{THE ANNUAL REPORT ON THE HEALTH OF OLD- BURY U.S.D., WORCESTERSHIRE, FOR 1898.}

Bx A. CUNNINGHAI, M.ßB.

WITH A SPECIAL REPORT ON ENTERIC FEVER IN OLDBURY.

\author{
BY G: H. FOSBROKE, D.P.ET., \\ County Medical Officer.
}

The town of Oldbury in Worcestershire has an estimated population of 25,000. The prevalence of enteric fever in Oldbury has been in excess of the average for the country for the last six years. In August, 1898 , the number of notified cases rose from 5 in the previous month to 36 , and to 46 in September, falling to 24,30 , and 16 in the succeeding months. The total number of cases for the year was 191, and of deaths 26. This sudden increase severely taxed the energies of the medical officer of health, who has held the office for eighteen years, and is engaged in practice there, as well as of the inspector, Mr. G. H. Robbins. The active measures taken by them in dealing with the individual cases are set forth in detail, concerning which the medical officer says that it was due to the activity and thoroughness with which they were carried out that the disease was checked so successfully. $\mathrm{He}$ also reports on the measures taken for the prevention of other diseases. The most interesting feature of the report is $\mathrm{a}$ special report to the Sanitary Committee of the Worcestershire C.C. made by the county medical officer, Dr. G. H. Fosbroke. The report gives a terse description of the many sanitary shortcomings of the town, and thoir special relation to the outbreak. He excludes the water-supply, the milk-supply, and the sewerage as direct causes of the outbreak on apparently sufficient grounds, although the condition of the cowsheds and the sewers is severely animadverted upon. In his opinion, the prevailing mode of excrement disposal was the cause of typhoid fever having been endemic in the past, and of its recent epidemic prevalence. With a sewage outlet and an abundant water-

that gocs over with the fat globules, and a minimum of casein in the imperfectly separated milk. The products of complete separation are :

Serarated Milk.

All the casein.

All the sugar.

Whereas those of Gärtner's process are:

Poor Mill.

Most of the casein.

Little albumin.

Little fat.

Some sugar.

\section{Cream.}

All the fat.

All the albumin.

Rich [Fat] Milk.

A littlo casein.

Most of the albumin.

Most of the fat.

Some sugar (to which more is added).-Rep. 
supply there had been no, active steps taken to convert the privymiddens, which have been the usual mode of excrement disposal in the Midlands in the past, into water-carriage closets. The inspector supplies a census showing 3,254 priry-middens, and only 328 w.c.'s, 30 slop-closets, and 21 pail-closets. Many of the middens were of ancient type, planned to be emptied as seldom as possible. The county medical officer quite endorses the opinion of Dr. Cunningham that the investigations pointed "to soil emanations, the result of the hot, dry season, and the use in large yards of common privy accommo. dation, as the cause of the outbreak, as well as the want of proper precautions by the occupants of infected houses." It is remarkable, but not specially noted in the report, that with all the conditions present which usually accompany a high diarrhœal mortality, including a birth-rate of 38 and an infantile mortality of 233 , there were only 13 deaths among children from diarrhœa, the diarrhœa death-rate for 1898 being $0 \cdot 6$. Among the recommendations made, the most obvious and necessary is the gradual replacing of the privy-middens with waterclosets. This, however, is one of the most difficult sanitary problems which most inland Local Authorities now have to deal with. The reports of medical officers of health are quite monotonous on the subject, but the usual course is to proceed along the lines of least resistance. The reports which have been published in this Journal of the appeal cases from Widnes, Eccles, and other places show that middens are lawfully established and privileged institutions, that they cannot be dealt with arbitrarily or in wholesale fashion, and that special provisional orders have been obtained by soveral towns to enable them to borrow money to repay the cost of their conversion. As an example of the terms of such an Order, the following extracts are given from the Wolverhampton Order :

\section{Local Government Board's Provisional Orders Confirmation} (No. 19) Act, 1896.

\section{Borougir of WoLveruasiptos.}

"ArT. IV.-(1) When n sewer and water supply sufticient for the purpose are reasonably nrailable, the Corporation may from time to time, by written noticc to the owner or owners of any building, requires any existing closet accommodation (other than a water-closet or \& waste-water-closet) provided at or in connection with such building, to be altered so as to be converted into a water-closet or waste-water-closet, which shall comply with the by-laws for the time being in force and shall communicate with a sewer; and they may also require a separate receptacle for ashes and house refuse to be provided at or in connection with such building.

" (2) If the owner or owners of any such building fail in any respect to comply with a notice from the Corporation (under subdivision (1) of this Article), the Corporation may at the expiration of $\Omega$ timue to be specified in the notice (not being less than fourteen days after the service of the suilice) do the work specitied in such notice; and may recover in a summary manner from the owner or owners the expenses incurred by the Corporation in so doing:

"Provided that, if in any case such alteration shall be required in respect of any existing closet accommodation which prior to the service of the notice under subdivision (1) of this Article shall not have been certified by the medical officer of health to be suficient for the necessities 
of the inhabitants of the building, nor to bo in such $a$ state as to create a nuisance or to be injurious to health, then the cost of providing and laying the drain and of connecting the same with the sewer and of fixing the water-closet or waste-water-closet, as the case may be, shall be borne by the Corporation, and the remainder of the said expenses shall be borne by the owner.

"(3) The Corporation may contribute towards the expenses incurred in making any alteration of any closet accommodation in pursunnce of this Article, in any case in which they may not be required to bear any part of such expense.

"Art. X-The Corporation may with the sanction of the Local Govern. ment Board, and subject to the provisions of this Order, borrow on the security of the Improvement Fund and Improvement Rate of the Borough such sums not excceding in the whole the sum of thirty-five thousand pounds as may from time to time be necessary for the purpose of defraying any expenditure of the Corporation in pursuance of subdivisions (2) and (3) of Article IV. of this Order."

There is nothing very exceptional or novel about the unsanitary conditions of Oldbury except that it has lagged behind other towns, nor in the persistence and active recrudescence of enteric fever by which they have been attended. The occasion affords, however, an admirable illustration-one which deserves to be recorded-of the part which a county medical officer of health is ablo to take in a special outbreak of disease in his county, acting with the approval of his council and the sanitary authority, and of intervening to advise, assist, and support the sanitary reforms which aro needed. He can so well supplement the shortcomings without detracting from the advantages of the position of a medical officer of health in the smaller towns who is also in practice. Vithout friction and with entente cordiale he can speak and act independently. The history of this inquiry emphasises the duty of county councils to appoint medical officers, and demonstrates the nature of the services that officer is able to render in exceptional and difficult circumstances to the Sanitary Authorities within the county area.

\section{THE BACTERIOLOGY OF SCARLET FEVER.}

That the germ of this disease is a streptococcus, or one of the micrococci swarming in the urine of persons suffering or convalescing therefrom, and not otherwise, all are agreed; but the failure of every attempt hitherto to obtain from the desquamated epithelial scales any cultures distinguishable from such as would follow the mere contact of the living hand with the medium has been a grave stumbling-block in the way of identifying the organism. If there bo any truth in the universal belief in the infectivity of the cast-off epithelium, it is in it, after the throat, that the microbe should be found. Some persons, realizing the difficulty, have gone so far as to accept the logical conclusion of denying the communication of the infection by " peeling," which they suggest is a mere coincidence-a phenomenon synchronous with the elimination of the microbes through the naso-pharyngeal mucus and the urine.

Dr. W. J. Class* ascribes the want of success that has attended even

* Chicago Mredical Recorder, 1899, p. 373. 